\title{
Potensi Nano Analog RN-18 (NARN-18) Berbasis Nanopartikel PLGA-CS- PEG dalam Penatalaksanaan HIV-1
}

\author{
Gede Setula Narayana ${ }^{1 *}$, I Kadek Wahyu Putra Dyatmika ${ }^{1}$, Widia Danis Swari ${ }^{1}$, \\ I Gede Putu Supadmanaba² \\ Program Studi Sarjana Kedokteran dan Profesi Dokter Fakultas Kedokteran Universitas \\ Udayana $^{1}$ \\ Departemen Biokimia Fakultas Kedokteran Universitas Udayana² \\ *e-mail: setulanarayana@gmail.com
}

\begin{abstract}
Abstrak
Acquired Immune Deficiency Syndrome (AIDS) merupakan penyebab dari kematian sekitar satu juta orang di dunia pada tahun 2016. Prevalensi infeksi Human Immunodeficiency Virus-1 (HIV1) di Indonesia masih sangat tinggi dan angka kematian akibat infeksi HIV-1 juga masih tinggi. Penatalaksanaan HIV/AIDS saat ini masih dikatakan kurang efektif dalam eradikasi HIV-1 di dalam tubuh, selain itu juga menimbulkan efek samping. Penelitian terbaru menemukan RN-18 sebagai molekul antagonis spesifik untuk viral infectivity factor (Vif) dan membuatnya terdegradasi sehingga dapat mempertahankan jumlah A3G intrasel. Penulisan tinjauan pustaka ini bertujuan untuk mengkaji potensi NARN-18 berbasis nanopartikel PLGA-CS-PEG melalui administrasi peroral dalam penatalaksanaan infeksi HIV-1. Tinjauan pustaka ini menggunakan metode kajian pustaka. Pencarian literatur dilakukan dengan menggunakan kata kunci "A3G", "HIV-1", "PLGA-CS-PEG", "RN-18", dan "Vif" pada mesin pencarian. Modalitas NARN-18 menggunakan molekul 13a yang merupakan analog dari RN-18 yang memiliki efektivitas serta kelarutan yang lebih baik dibanding molekul sebelumnya. Enkapsulasi 13a menggunakan nanopartikel PLGA, PEG, dan kitosan (CS) sebagai nanopartikel pembawa menyebabkan modalitas ini dapat diadministrasikan secara peroral dan langsung menuju sel T melalui aliran darah serta meningkatkan efisiensi dalam drug release dan drug loading. NARN-18 yang dikonstruksi menggunakan nanopartikel PLGA-PEG-CS menyebabkan modalitas dapat diadministrasikan secara peroral dan meningkatkan waktu paruh dari modalitas serta meningkatkan efek penghambatan dari RN-18. Dengan demikian, kombinasi ini merupakan terapi yang potensial dalam penatalaksanaan infeksi HIV-1.
\end{abstract}

Kata Kunci: A3G, HIV-1, PLGA-CS-PEG, RN-18, Vif

\section{Potenstial of Nano Analogue RN-18 (NARN-18) Based on PLGA-CS-PEG Nanoparticles in Management of HIV-1 Infection}

\begin{abstract}
Acquired Immune Deficiency Syndrome (AIDS) is the cause of death of million people in the world in 2016. The prevalence of Human Immunodeficiency Virus-1 (HIV-1) infection in Indonesia is still high and number of death caused by HIV-1-related diseases shows an apprehensive number. Treatment of HIV/AIDS nowadays is not effective to eradicate HIV-1 and also cause adverse effects. Previous research found $R N-18$ as a specific antagonistic molecule for viral infectivity factor (Vif) that can trigger Vif degradation and maintain intracellular A3G level. The aim of this review is to examine the potential of NARN-18 based PLGA-CS-PEG
\end{abstract}


Potensi Nano Analog RN-18 (NARN-18) Berbasis Nanopartikel PLGA-CS-PEG dalam...

Gede Setula Narayana, I Kadek Wahyu Putra Dyatmika, Widia Danis Swari,

I Gede Putu Supadmanaba

nanoparticles through oral administration in the management of HIV-1 infection. Method of this article is using literature review method. Literature searching is done by using "A3G", "HIV1", "PLGA-CS-PEG", "RN-18", and "Vif" as keywords in search engine. 13a molecule, that is the analogue of $R N-18$, is used in the modality because it has better effectiveness and solubility compared with RN-18. By using PLGA, PEG, and chitosan (CS) as nanoparticles that carries RN18 analogue makes the modality can be taken orally and targets $T$ cell as soon as it enters the blood stream. It also can increase the efficiency of drug release and drug loading of the modality. NARN-18 constructed by using PLGA-PEG-CS nanoparticle makes the modality can be administered orally, increase its half-life in the body, and also increase the inhibition effect of $R N-18$ analogue. Therefore, this combination is one of the potential therapy in HIV-1 infection treatment.

Keywords: A3G, HIV-1, PLGA-CS-PEG, RN-18, Vif

\section{PENDAHULUAN}

Acquired Immune Deficiency Syndrome (AIDS) merupakan penyakit yang timbul akibat infeksi Human Immunodeficiency Virus (HIV) yang menyerang dan menurunkan sistem kekebalan tubuh. Dewasa ini, penyakit HIV/AIDS memiliki tingkat penyebaran yang sangat tinggi di dunia. Menurut data dari WHO pada penghujung tahun 2016 terdapat sekitar 36.7 juta orang di dunia terinfeksi HIV dan sekitar 1 juta orang di seluruh dunia meninggal akibat penyakit yang berkaitan dengan AIDS (Lucas dan Nelson, 2014). Persebaran HIV di setiap regio WHO di dunia sangat beragam dengan regio Asia Tenggara berada pada peringkat dua dalam angka infeksi HIV setelah Afrika dengan jumlah sekitar 3.5 juta orang (Lucas dan Nelson, 2014).

Di Indonesia, masyarakat yang terinfeksi HIV terhitung sangat tinggi. Pada tahun 2018, terdapat sekitar 640.000 penduduk Indonesia terinfeksi HIV (UNAIDS,
2019). Tidak hanya itu, angka kematian HIV di Indonesia juga sangat memprihatinkan. Selalu terjadi kenaikan angka kematian akibat penyakit yang berkaitan dengan HIV/AIDS dari tahun ke tahun. Pada tahun 2005 terdapat sekitar 8.800 kematian, kemudian pada tahun 2010 meningkat menjadi 23.000 kematian, dan yang terakhir pada tahun 2016 terdapat sekitar 38.000 kematian (UNAIDS, 2019).

Saat ini sudah terdapat beberapa macam obat yang digunakan dalam penatalaksanaan infeksi HIV. Obat-obatan yang digunakan dalam penatalaksanaan HIV disebut sebagai obat antiretroviral (ARV) yang berfungsi untuk mengontrol pertumbuhan virus di dalam tubuh, meningkatkan sistem kekebalan tubuh, dan untuk mengurangi gejala-gejala yang timbul akibat infeksi HIV. Terdapat beberapa macam obat antiretroviral seperti nucleoside reverese transcriptase inhibitor (NRTI), nonnucleoside reverse transcriptase inhibitor 
(NNRTI), protease inhibitor (PI), integrase Inhibitor, dan lain-lain. Obat NRTI dan NNRTI bertujuan untuk mengendalikan pertumbuhan virus HIV di dalam tubuh dengan cara berinteraksi dengan enzim reverse transcriptase HIV. Golongan NRTI berfungsi menghambat pembentukan DNA virus yang utuh dengan cara berkompetisi dengan nukleotida natural untuk diintroduksikan ke dalam DNA virus. Golongan NNRTI berinteraksi dengan enzim reverse transcriptase virus dan menghambat kerjanya secara langsung. Golongan PI dan Integrase inhibitor bekerja dengan cara menghambat enzim protease dan integrase sehingga mencegah proses replikasi virus berjalan sampai akhir (Cihlar and Ray, 2010; Usach et al, 2013; Wensing, van Maarseveen dan Nijhuis, 2010; Hajimahdi dan Zarghi, 2016).

Meskipun telah digunakan secara umum, obat-obat ARV masih tidak mampu memberantas HIV secara tuntas. Hal ini disebabkan karena HIV merupakan virus yang memiliki RNA sebagai materi genetiknya sehingga mudah mengalami mutasi dan meningkatkan kemampuannya untuk beradaptasi dengan obat-obat yang sudah ada. Selain itu ARV juga memiliki efek samping yang teramati pada pasien HIV. Pada penggunaan zidovudine (AZT), salah satu NRTI, ditemukan hiperpigmentasi pada kuku dan oral pasien. Selain itu, beberapa pasien mengalami anemia parah akibat penggunaan AZT. Penggunaan stavudine (d4T) dan lamivudine (3TC) juga memiliki efek samping berturut-turut yaitu peripheral neuropathy dan pankreatitis. Sedangkan, pada pasien dengan terapi PI berisiko untuk mengalami peningkatan kolesterol dalam darahnya hingga terjadi resistensi insulin yang berujung pada diabetes mellitus tipe 2 (Sharma et al, 2008).

Melihat beberapa kekurangan yang ada pada terapi HIV saat ini, penulis mengangkat Nano Analog RN-18 (NARN-18) sebagai inovasi baru dalam penatalaksanaan HIV. Pada tahun 2008 telah ditemukan molekul baru yang diberi nama $\mathrm{RN}-18$ yang merupakan molekul yang dapat menghambat dan mengurangi jumlah virus di tubuh. Molekul ini bekerja dengan cara menghambat degradasi APOBEC3G (A3G) oleh viral infectivity factor (Vif) HIV sehingga dapat melakukan fungsi antiretroviralnya dengan maksimal (Nathans et al, 2008). Selain itu, penelitian terbaru menunjukkan susunan kimia molekul ini dapat dimodifikasi untuk mengingkatkan efisiensi kerjanya secara signifikan (Zhou et al, 2017). Dengan menggunakan bantuan nanopartikel poly(lactic-co-glycolic acid) (PLGA) dan kitosan (CS) yang ditambah dengan polyethylene glycol (PEG), penghantaran molekul analog $\mathrm{RN}-18$ ini ke tubuh dapat dilakukan secara oral dan dengan tingkat 
Potensi Nano Analog RN-18 (NARN-18) Berbasis Nanopartikel PLGA-CS-PEG dalam...

Gede Setula Narayana, I Kadek Wahyu Putra Dyatmika, Widia Danis Swari,

I Gede Putu Supadmanaba

efisiensi yang tinggi. Oleh karena itu, tujuan dari penulisan tinjauan pustaka ini yaitu untuk mengkaji potensi NARN-18 berbasis nanopartikel PLGA-CS-PEG melalui administrasi peroral dalam penatalaksanaan infeksi HIV-1. Penulisan karya ilmiah ini menggunakan metode kajian pustaka. Data kualitatif dan kuantitatif diambil dari berbagai literatur yang relevan dengan permasalahan yang dibahas. Kata kunci yang digunakan pada mesin pencarian yaitu "A3G", “HIV-1", “PLGA-CS-PEG”, “RN-18”, dan "Vif". Data yang terkumpul diseleksi dan diurutkan sesuai topik, selanjutnya dilakukan penyusunan karya tulis.

\section{PEMBAHASAN}

\section{Gambaran Umum Patogenesis HIV-1}

Human Immunodeficiency Virus merupakan virus yang tergolong ke dalam famili Retroviridae dan genus Lentivirus (Seitz, 2016). Virus tersebut memiliki 2 subtipe yaitu HIV-1 dan HIV-2, yang mana HIV-1 lebih berbahaya karena dapat menginfeksi manusia sedangkan, virus HIV-2 memiliki kapasitas yang lebih buruk untuk dapat menginfeksi sel (Seitz, 2016). Infeksi HIV-1 dimulai dari pengikatan molekul gp120 pada amplop virus dengan molekul CD4+ dan sebuah reseptor chemokin CCR5 atau CXCR4 pada membran sel target (Wilen et al, 2012; Engelman dan Cherepanov, 2012). Berbeda dengan retrovirus pada umumnya yang masuk ke sel inang degan endositosis, HIV-1 masuk ke dalam sel inang melalui fusi amplop virus dengan membran sel inang (Seitz, 2016). Virus yang telah melepaskan kapsidnya ke sitoplasma juga melepaskan beberapa jenis enzim, termasuk enzim reverse transcriptase (RT), serta RNA-nya. Materi genetik RNA virus kemudian ditranskripsi balik oleh RT menjadi complementary DNA atau cDNA ( $\mathrm{Hu}$ dan Hughes, 2012; Cimarelli dan Darlix, 2014). Dilanjutkan dengan sintesis DNA antisense virus oleh DNA polymerase inang membentuk DNA untai ganda yang nantinya akan berintegrasi dengan genom sel inang menggunakan enzim integrase.

Genom virus yang telah terintegrasi akan diekspresikan untuk sintesis protein struktural beserta enzim virus. Selain protein utama yang dimiliki oleh retrovirus pada umumnya (seperti Gag, Pol, dan Env polyprotein), genom HIV juga mengkodekan protein aksesoris lainnya antara lain Tat, Rev, Nef, Vpu, Vpr, dan Vif (Das et al, 2011; Zhao dan Bukrinsky, 2014; Andrew dan Strebel, 2014; Collins dan Collins, 2014). Keenam protein aksesoris tersebut berfungsi untuk menunjang infektivitas virus ke sel lainnya dengan berbagai mekanisme yang berbeda untuk setiap protein aksesoris. Salah satu protein aksesoris HIV-1 yang berperan adalah Vif (Viral infectivity factor). Protein tersebut bekerja dengan cara membajak Cullin E5 
ubiquitin ligase sel inang yang digunakan untuk mendegradasi Apolipoprotein B mRNA editing enzyme, catalytic polypeptide-like $3 G$ (APOBEC3G atau A3G) melalui jalur ubiquitinproteasome system (Maartens et al, 2014). A3G merupakan host restriction factor sel tubuh manusia yang akan ikut terbawa oleh virus saat proses budding, bekerja dengan beberapa macam cara untuk menghambat virus menginfeksi sel lainnya (Sheehy et al, 2002; Desimmie et al, 2014). Dengan didegradasinya A3G oleh Vif, partikel virus yang baru terbentuk akan aman dari kontaminasi A3G inangnya sehingga memungkinkan untuk meningkatkan persebaran virus di dalam tubuh.

RN-18 sebagai Agen Antiviral Baru dalam Penatalaksanaan HIV-1

Pada penelitian yang dilakukan oleh Nathans et al (2008), ditemukan suatu molekul dengan nama kimia $\mathrm{N}-(2-$ metoksifenil)-2-((4-nitrofenil)thio) benzamida atau $\mathrm{RN}-18$ yang dapat menginhibisi aktivitas Vif pada sel (Nathans et al, 2008). Molekul tersebut merupakan antagonis spesifik dari Vif namun bukanlah sebuah inhibitor dari proteasom secara umum. Mekanisme kerja $\mathrm{RN}-18$ yaitu dengan mengganggu interaksi Vif-A3G dan memicu degradasi Vif. Selain itu, $\mathrm{RN}-18$ juga diduga dapat berinteraksi dengan protein adapter pada kompleks Vif-A3G, membuat Vif menjadi kurang stabil, sehingga meningkatkan turnover protein tersebut
(Nathans et al, 2008). Penelitian lebih lanjut diperlukan untk mengetahui mekanisme kerja dari RN-18 secara detail.

Penelitian selanjutnya oleh Zhou et al (2017) mengenai Structure-activity Relationship dari RN-18 menemukan bahwa efektifitas RN-18 dapat tingkatkan dengan mengubah struktur kimianya. Penggantian rantai samping pada cincin benzena dari RN18 dengan gugus amino (-NH2) dapat meningkatkan efektivitasnya. Molekul analog tersebut dinamakan 12c dengan efektivitas molekul meningkat sebesar 150 kali dibandingkan molekul awal dengan EC50 sebesar $1.54 \mu \mathrm{M}$.

Zhou et al (2017) juga melakukan solubility study untuk meningkatkan solubilitas $12 \mathrm{c}$ di dalam air dengan menambahkan glisin pada rantai samping cincin benzena. Hasil dari modifikasi tersebut adalah molekul dengan nama 13a yang memiliki solubilitas 2600 kali lebih baik dibandingkan dengan $12 \mathrm{c}$ dengan kelarutan dalam air sebesar $1730 \mu \mathrm{g} / \mathrm{mL}$. Temuan ini menandakan molekul 13a merupakan salah satu molekul yang sangat potensial untuk dapat menghambat replikasi HIV-1 dalam tubuh.

Mekanisme Konstruksi, Administrasi dan Distribusi Nano Analog RN-18 (NARN-18)

Nanopartikel saat ini menjadi pilihan utama dalam delivery drug system karena dapat meningkatkan efektivitas obat (Neeta 
Potensi Nano Analog RN-18 (NARN-18) Berbasis Nanopartikel PLGA-CS-PEG dalam...

Gede Setula Narayana, I Kadek Wahyu Putra Dyatmika, Widia Danis Swari,

I Gede Putu Supadmanaba

et al, 2016). Nanopartikel yang berpotensi pada NARN-18 adalah kitosan dan PLGA-PEG diblock copolymer. Kitosan dan PLGA-PEG memiliki sifat bioavailabilitas yang tinggi sehingga aman dalam penggunaan secara in vitro dan in vivo. Menurut penelitian Rafiei and Haddadi (2017) dan Parveen dan Sahoo (2011), Kitosan dan PLGA-PEG mampu menghantarkan obat dalam kapasitas yang besar, stabilitas obat yang tinggi, pengiriman obat yang tepat, dan pelepasan obat dari nanopartikel secara efektif. Penambahan kitosan dan PLGA-PEG memiliki potensi meningkatkan waktu paruh modalitas di dalam sirkulasi darah dengan cara mencegah fagositosis oleh makrofag melalui inhibisi interaksi protein serum dengan nanopartikel (Rafiei and Haddadi, 2017; Khan et al, 2017; Parveen dan Sahoo, 2011; Taamalli et al, 2019).

Metode yang digunakan dalam persiapan NARN-18 adalah metode double emulsification solvent evaporation (W1/O/W2). Metode ini terbagi menjadi ke dalam tiga fase yaitu first water phase, organic phase, dan second water phase. Sebagai tahap awal first water phase (W1), analog RN-18 dilarutkan dengan $0,2 \mathrm{~mL}$ deionized (DI) water dalam tabung sentrifugasi $1,5 \mathrm{~mL}$ untuk menghasilkan larutan first water phase (W1).

Tahap berikutnya yaitu organic phase, pada tahap ini melakukan preparasi PLGA-
PEG, sebanyak 0.3 gr PLGA-PEG dilarutkan kedalam $6 \mathrm{~mL} \quad \mathrm{DCM} \quad(5 \% \mathrm{w} / \mathrm{v}), \quad \mathrm{DCM}$ merupakan pelarut organik yang digunakan untuk menghasilkan larutan organic phase (Rafiei and Haddadi, 2017).

Tahap berikutnya yaitu W1/O, kedua larutan dari fase W1 dan O dilarutkan lalu dihomogenisasi menggunakan vorteks selama 30 detik dan disonikasi pada $30 \mathrm{~W}$ selama 2 menit untuk memperoleh partikel berukuran nano. Tahap berikutnya Second water phase (W2), larutan Kitosan (12\% w/w) dilarutkan kedalam $1 \%$ asam glasial asetik, disaring kemudian ditambahkan ke larutan polyvinyl alcohol (5\%).

Tahap berikutnya emulsi kedua (O/W2), larutan emulsi pertama ditambah dengan larutan W2 lalu dihomogenisasi menggunakan vorteks selama 60 detik dan disonikasi pada $30 \mathrm{~W}$ selama 2 menit untuk mendapatkan nanopartikel PLGA-PEG yang terbungkus dengan kitosan (Rafiei and Haddadi, 2017; Khan et al, 2017).

Untuk tahap terakhir, emulsi diaduk secara perlahan selama 1 jam di (chemical hood) hingga DCM habis terevaporasi dan didiamkan selama 45 menit. Selanjutnya, disentrifugasi pada $10.000 \mathrm{rpm}$ selama 15 menit untuk menghasilkan suspensi dari nanopartikel. Suspensi dari nanopartikel ditambahkan dengan $1 \mathrm{~mL}$ phosphate buffered saline (PBS) lalu di vorteks selama 1 menit. Suspensi tersebut selanjutnya 
didinginkan dan dikeringkan sehingga memperoleh Nano Analog $\mathrm{RN}-18$ yang siap untuk diadministrasikan (Rafiei and Haddadi, 2017; Khan et al, 2017; Parveen dan Sahoo, 2011).

Jalur peroral menjadi pilihan dalam administrasi NARN-18 karena sangat mudah dan tidak mengganggu kenyamanan pasien (Kumar et al, 2016). Namun, kelemahan dari administrasi peroral adalah harus melewati sistem gastrointestinal terlebih dahulu. Kitosan dapat melindungi NARN-18 pada suasana asam lambung.

Pada $\mathrm{pH}$ yang sangat rendah kitosan akan menjadi larut air karena asam amino yang terdapat pada kitosan mengalami protonasi (Parveen dan Sahoo, 2011). Ketika mencapai saluran gastrointestinal, NARN-18 akan direabsorbsi melewati sel epitel usus halus. Kitosan memiliki sifat mukoadesif yang mampu berikatan dengan mukus pada saluran gastrointestinal ( $\mathrm{Wu}$ et al, 2012). Kitosan dapat melewati sel epitel dengan memutuskan tight junction pada membran sel epitel usus halus dengan redistribusi dari filament aktin dan translokasi protein integral seperti Zonnula occludens-1 (ZO-1), Occludin, dan Claudin-4 (Cldn4) dari membran sel ke sitosol. Selanjutnya NARN18 akan ditransportasi menuju membran basal sel epitel usus halus sehingga dapat berdifusi dengan pembuluh darah (Malatesta et al, 2015; Zhang et al, 2014; Yeh et al, 2011).

Selanjutnya NARN-18 akan berdifusi ke dalam sistem pembuluh darah sistemik. Namun, sebelum mencapai sel target NARN18 harus melewati first pass effect pada liver. Nanopartikel PLGA-PEG mampu melewati first pass effect pada hati sehingga bioavailabilitas dari NARN-18 tidak berkurang. NARN-18 akan mencapai jaringan limpa karena target dari NARN-18 merupakan sel T Helper 1. Internalisasi PLGAPEG pada sel $\mathrm{T}$ Helper 1 menggunakan clathrin-mediated endosomal (Li et al, 2017; Hamdy et al, 2011; Aguilar, 2013).

NARN-18 yang sudah terinternalisasi melalui endosomal akan keluar dari endosomal dengan cepat setelah 10 menit inkubasi (Li et al, 2017; Hamdy et al, 2011; Aguilar, 2013; Chandra et al, 2014). Analog RN-18 akan terlepas dari nanopartikel PLGAPEG sehingga Analog RN-18 akan membentuk kompleks dengan Vif-APOBEC3G dan mendegradasi Vif. PLGA-PEG selanjutnya akan didegradasi menjadi asam laktat dan asam glikolat. Hasil dari degradasi PLGA-PEG akan masuk ke dalam siklus krebs. Selain masuk ke dalam jalur metabolisme nanopartikel PLGA-PEG dan kitosan memiliki sifat water soluble sehingga dapat di ekskresi oleh ginjal dalam urin (Yeh et al, 2011; Li et al, 2017). 
Potensi Nano Analog RN-18 (NARN-18) Berbasis Nanopartikel PLGA-CS-PEG dalam...

Gede Setula Narayana, I Kadek Wahyu Putra Dyatmika, Widia Danis Swari,

I Gede Putu Supadmanaba

Mekanisme Kerja dan Efek Penghambatan dari NARN-18

Molekul

NARN-18

yang

diadministrasikan akan menuju sel target yang mengekspresikan A3G, disebut juga sel nonpermisif seperti sel $T$ CD4+ dan monocyte-derived macrophage (Madani and Kabat, 2000; Simon et al, 2015). Molekul tersebut dapat mencegah penyebaran HIV-1 dengan cara berikatan dengan kompleks VifA3G, mengganggu interaksi kedua protein tersebut, dan membuat Vif terdegradasi (Nathans et al, 2008). Terdegradasinya Vif akan mencegah A3G terdegradasi serta menyebabkan peningkatan jumlah A3G di dalam sel. Dengan demikian, A3G dapat melaksanakan fungsinya sebagai host restriction factor dan mencegah HIV-1 menginfeksi sel lainnya dengan mekanisme deaminase-independent activity dan deaminase-dependent activity.

\section{Deaminase-independent activity}

Salah satu cara A3G dalam menghambat pertumbuhan HIV-1 yaitu dengan menggunakan kemampuan fisik dari enzim tersebut. Terdapat dua mekanisme deaminase-independent activity antara lain (Gambar 1):

1. Memblokir reverse transcriptase secara fisik (roadblock)

Afinitas A3G yang tinggi terhadap polinukleotida tunggal memungkinkan enzim tersebut untuk berinteraksi dengan RNA virus dan menghambat kerja RT secara fisik. Inhibisi aktivitas RT terjadi akibat A3G membentuk oligomer pada RNA virus sehingga menghalangi RT untuk dapat berpindah dari satu nukleotida ke nukleotida lain (Okada and Iwatani, 2016; Adolph et al, 2013; Chaurasiya et al, 2013).

2. Memproduksi substrat DNA yang buruk untuk diintegrasikan ke dalam genom sel Selain A3G dapat bekerja dengan mengurangi efisiensi dan spesifisitas dari pemrosesan tRNA serta penghilangan tRNA saat proses transkripsi balik, juga dapat menghambat pelepasan tRNA dari DNA substrat menghasilkan ujung DNA baru yang tidak normal dan mencegah DNA virus untuk dapat berintegrasi dengan DNA sel inang (Cadima-Couto and Goncalves, 2010; Wang et al, 2012).

\section{Deaminase-dependent activity}

Cara lain A3G menghambat replikasi HIV-1 yaitu dengan mengatalisis reaksi deaminasi nukleotida virus. Terdapat dua mekanisme yang memfasilitasi fungsi tersebut, antara lain (Gambar 1):

1. Memicu degradasi transkrip oleh enzim uracil DNA glycosilase (UDG)

Pada penelitian Okada and Iwatani (2016) disebutkan bahwa DNA virus akan sulit diintegrasikan ke dalam genom sel inang apabila mengalami banyak substitusi menjadi urasil. Hal ini 
disebabkan oleh adanya enzim uracil DNA glycosilase (UDG) di dalam nukleus sel inang yang mendegradasi nukleotida yang memiliki banyak basa urasil, sehingga integrasi DNA virus ke dalam genom akan terhalangi (Okada and Iwatani, 2016; Weil et al, 2013).

2. Konversi dC menjadi dU pada minus strand ssDNA virus sehingga menyebabkan hipermutasi dG menjadi $\mathrm{dA}$ pada genom virus

Virus dengan genom ssRNA seperti HIV-1 rentan mengalami mutasi. Banyaknya mutasi yang terjadi akan meningkatkan diversifikasi sekuens nukleotida yang mengakibatkan virus semakin mudah untuk beradaptasi terhadap perubahan lingkungan. Apabila mutasi yang terjadi dalam satu waktu melebihi ambang batas, maka dapat menyebabkan error catastrophe yang berujung pada kegagalan replikasi virus (Okada and Iwatani, 2016; Rawson et al, 2015). Mekanisme kerja A3G yang dapat mengatalisis reaksi deaminasi cytocine (dC) menjadi uracil (dU) pada DNA virus untai negatif mengakibatkan virus membentuk DNA untai positif yang sesuai dengan template yang salah (Wang et al, 2013). Kesalahan sintesis pada untai positif tersebut mengakibatkan virus mengalami hipermutasi guanine (dG) menjadi adenine (dA) (Kobayashi et al, 2014). Perubahan sekuens pada DNA ini akan menyebabkan beberapa dampak negatif pada virus, salah satunya yaitu penggantian asam amino triptofan menjadi kodon stop prematur sehingga menghentikan proses translasi protein virus dan menghambat replikasi virus (Armitage et al, 2012). 
Potensi Nano Analog RN-18 (NARN-18) Berbasis Nanopartikel PLGA-CS-PEG dalam...

Gede Setula Narayana, I Kadek Wahyu Putra Dyatmika, Widia Danis Swari,

I Gede Putu Supadmanaba

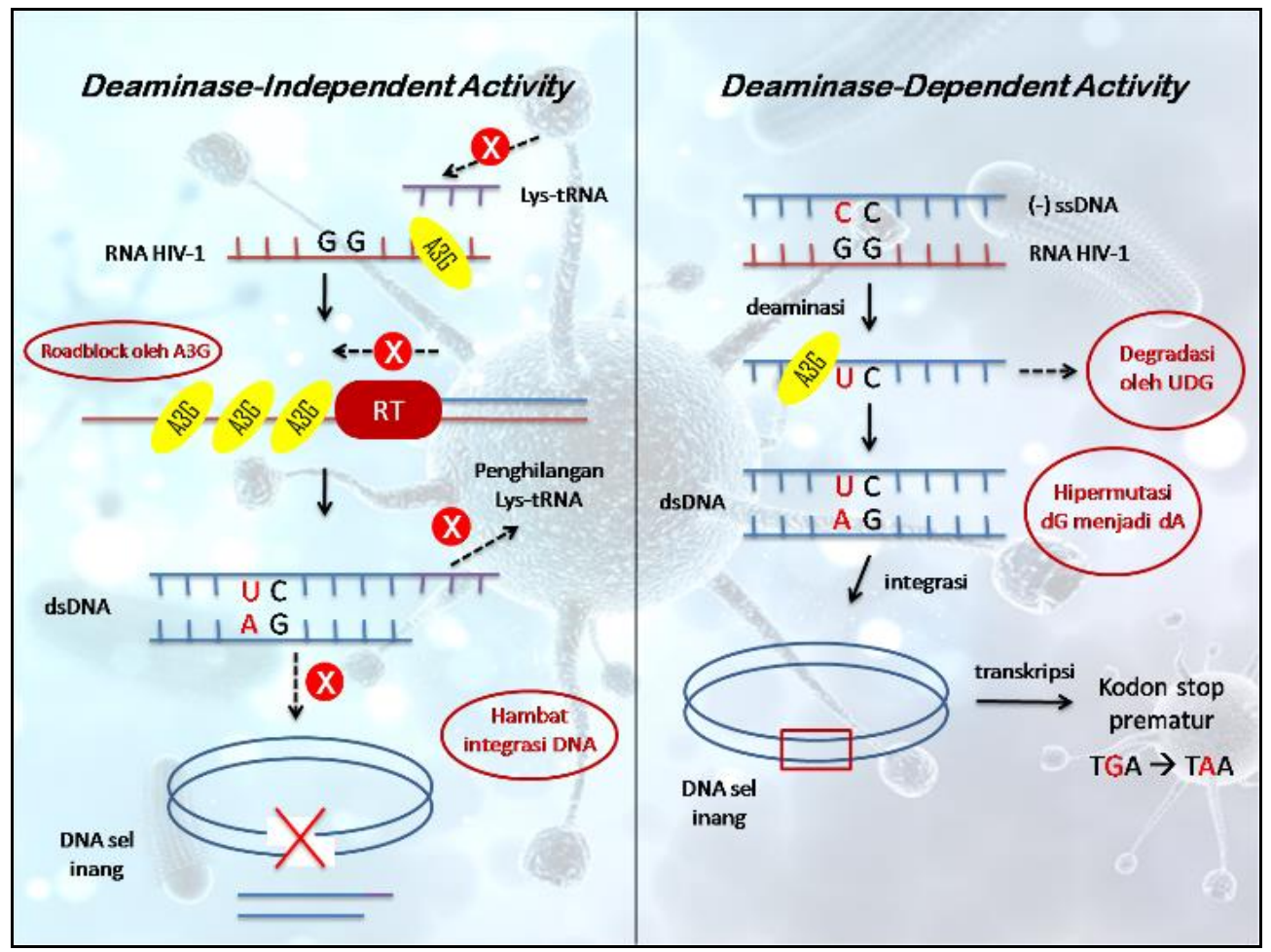

Gambar 1. Mekanisme kerja A3G terhadap proses replikasi HIV-1 dalam sel non-permisif

Efisiensi Mekanisme Kerja dan Efek dengan aktivitas RT pada sel non-permisif H9 Penghambatan dari Nano Analog RN-18 tanpa perlakuan (Gambar 2; Nathans et al, (NARN-18) Dalam Eradikasi Virus HIV-1 2008). Penurunan aktivitas RT berkorelasi

Pada penelitian Nathans (2008) telah ditunjukkan efektivitas RN-18 dalam inhibisi replikasi HIV-1 (Nathans et al, 2008). dengan kadar RN-18 yang diberikan, semakin tinggi kadar yang diberikan maka semakin tinggi pula efek penghambatannya.

Penurunan aktivitas RT teramati pada sel non-permisif H9 yang diberi perlakuan dengan RN-18 (Gambar 2) jika dibandingkan
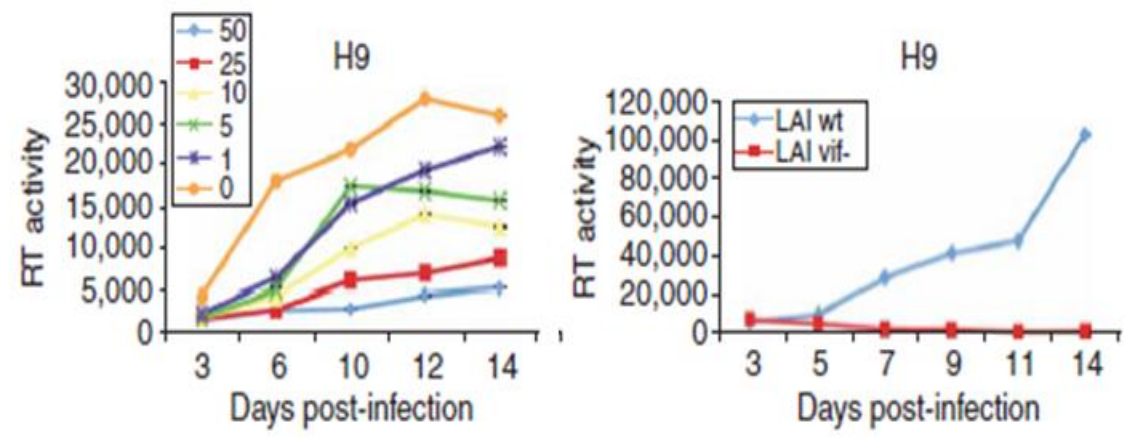

Gambar 2. Perbandingan efek penghambatan replikasi virus HIV-1 berdasarkan dosis RN-18 pada sel nonpermisif $\mathrm{H} 9$ dan kontrol (Zhou et al, 2017). 
Modalitas NARN-18 berisikan molekul $13 a$ yang merupakan analog dari $\mathrm{RN}-18$ yang dinanoenkapsulasi menggunakan PLGA-PEG yang digabung dengan kitosan. Molekul 13a dibuat dengan mengubah RN-18 menjadi molekul 12c terlebih dahulu dengan substitusi rantai samping pada cincin benzena dengan gugus amino. Perubahan struktur molekul tersebut meningkatkan efektifitas dari molekul sebelumnya dengan EC50 sebesar $1.54 \mu \mathrm{M}$ (Zhou et al, 2017). Peningkatan efektivitas tersebut ditunjukkan dengan ditemukannya peningkatan kadar A3G yang terkonservasi pada sel yang diberi perlakuan dengan $12 \mathrm{c}$ dibandingkan dengan sel yang diberi perlakuan dengan RN-18. Jumlah A3G yang terobservasi dalam sel berbanding lurus dengan kadar 12c yang diintroduksikan ke dalam sel.

Meskipun 12c sudah menunjukkan peningkatan efektivitas kerja yang cukup signifikan, namun masih terdapat kekurangan yaitu molekul tersebut merupakan molekul hidrofobik. Untuk mengatasi hal tersebut, Zhou et al juga melakukan studi mengenai kelarutan molekul untuk dapat meningkatkan kelarutan $12 \mathrm{c}$ dalam air dan didapatkan penambahan asam amino glisin pada rantai samping benzena 12c akan meningkatkan kelarutan molekul tersebut. Molekul $12 \mathrm{c}$ yang awalnya memiliki kelarutan dalam air sebesar $0.66 \mu \mathrm{g} / \mathrm{mL}$ dapat ditingkatkan sebanyak 2600 kali menjadi $1730 \mu \mathrm{g} / \mathrm{mL}$. Molekul derivat hasil modifikasi $12 \mathrm{c}$ ini merupakan molekul 13a yang akan digunakan dalam modalitas NARN18. Modifikasi $12 \mathrm{c}$ ini menjadi 13a juga meningkatkan efektivitas kerjanya dengan EC50 sebesar $0.248 \mu \mathrm{M}$ (Zhou et al, 2017).

\section{Efisiensi Drug Loading dan Drug Release pada NARN-18}

Enkapsulasi NARN-18 dengan PLGA-CSPEG memberikan banyak keuntungan dari segi drug loading dan drug release. Penggunaan nanopartikel tersebut mampu meningkatkan drug loading dan drug release hingga lebih efisien jika dibandingkan tanpa nanopartikel tersebut. Penelitian Rafiei and Haddadi (2017), membuktikan bahwa pada pemberian PLGA-PEG dapat meningkatkan drug loading dan drug release dari Docetaxel jika dibandingkan dengan PLGA. Perbandingan drug loading PLGA dan PLGAPEG sebesar $5.58 \pm 0.24 \mu \mathrm{g} / \mathrm{mg} \quad \mathrm{NP}$ (37.25\% $\pm 1.60 \%$ drug-loading efficiency) dan $8.89 \pm 0.10 \mu \mathrm{g} / \mathrm{mg}$ NP $(59.30 \% \pm 0.70 \%$ drugloading efficiency) (Gambar 3A; Sheehy et al, 2002).

Penelitian Rafiei and haddadi (2017) juga menunjukan perbandingan drug release dari PLGA dan PLGA-PEG. Pelepasan docetaxel dari PLGA dan PLGA-PEG terhitung $25 \%$ dan $49 \%$ setelah 24 jam masa inkubasi. Pelepasan PLGA-PEG dapat lebih cepat dikarenakan PEG dapat menarik air menuju permukaan PLGA menyebabkan PLGA 
Potensi Nano Analog RN-18 (NARN-18) Berbasis Nanopartikel PLGA-CS-PEG dalam...

Gede Setula Narayana, I Kadek Wahyu Putra Dyatmika, Widia Danis Swari,

I Gede Putu Supadmanaba

menjadi terhidrasi (Sheehy et al, 2002).

Penelitian Suphiya Parveen menunjukan

terjadi penurunan drug loading pada

paclitaxel yang dienkapsulasi menggunakan

kitosan dan PLGA-PEG (Anderson dan Hope,

2008). Penurunan ini dapat diatasi dengan

lama waktu degradasi dari kitosan dan PLGA-

PEG yang mencapai 72 jam yang akan

dijelaskan lebih lanjut. Sehingga penulis

berasumsi bahwa dengan penggunaan PLGA-

PEG sebagai enkapsulasi Analog RN-18 dapat

meningkatkan drug loading dan drug release

ketika NARN-18 telah mencapai sel $T$ Helper

1. Penambahan kitosan juga mampu meningkatkan drug loading karena Analog $\mathrm{RN}-18$ memiliki sifat larut air sehingga memudahkan proses enkapsulasi (Anderson dan Hope, 2008).

Perpanjangan Lama Waktu Paruh Nano Analog RN-18

Degradasi dari NARN-18 yang terenkapsulasi menggunakan nanopartikel kitosan dan PLGA-PEG untuk menjadi setengah konsentrasi membutuhkan waktu cukup lama. Nanopartikel tersebut memiliki efek untuk mempertahankan konsentrasi
NARN-18 sehingga dapat efek kerjanya tetap bertahan dalam waktu yang cukup lama.

Lamanya waktu paruh ini ditunjukan pada penelitian Rafiei and Haddadi (2017) dan Parveen dan Sahoo (2011). Penelitian Rafiei and Haddadi (2017) menunjukan serum darah yang diuji masih mengandung docetaxel yang terenkapsulasi menggunakan PLGA-PEG setelah 24 jam administrasi (Sheehy et al, 2002). Peningkatan lama waktu ini disebabkan karena ukuran dari PLGA-PEG lebih besar jika dibandingkan dengan penambahan PLGA saja dan kelarutan. Penelitian Suphiya Parveen menunjukan peningkatan yang lebih lama ketika kitosan ditambahkan pada PLGA-PEG (Gambar 3B; Sheehy et al, 2002).

Penelitian tersebut menggunakan paclitaxel yang terenkapsulasi dengan kitosan dan PLGA-PEG. Setelah 72 jam, masih adanya paclitaxel dalam serum yang diuji (Anderson dan Hope, 2008). Berdasarkan data-data tersebut penulis memiliki asumsi bahwa jika pengaplikasian kitosan dan PLGAPEG ke NARN-18 mampu meningktakan lama waktu degradasi dari NARN-18 (Gambar 3C). 


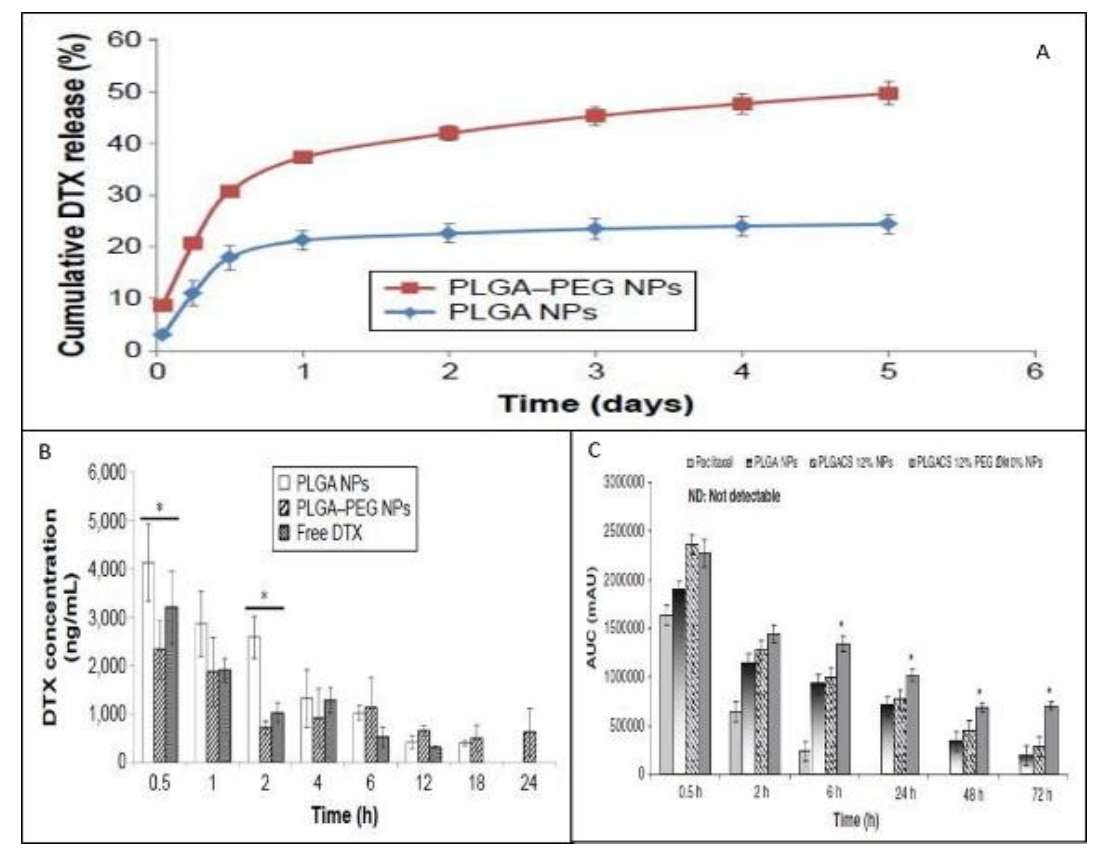

Gambar 3. (A) Drug Release Docetaxel yang terenkapsulasi dengan PLGA dan PLGA-PEG20; (B) Waktu Paruh dari Paclitaxel tanpa enkapsulasi dan Paclitaxel yang terenkaspulasi dengan PLGA, PLGA-CS, dan PLGA-CS-PEG21; (C) Waktu Paruh Docetaxel tanpa enkapsulasi dan Docetaxel yang terenkapsulasi PLGA dan PLGA-PEG (Sheehy et al, 2002).

\section{Efek Immunostimulator dari PLGA}

Selain sifat PLGA yang mudah dimetabolisasi menjadi asam laktat dan asam glikolik oleh tubuh. PLGA memiliki target yang spesifik pada sel $T$ helper dan makrofag sehingga mampu memberikan efek imunotimulator pada sel $T$ helper dan makrofag (Ebrahimian et al, 2016; Fairley et al, 2013; Sarti et al, 2011). PLGA juga memiliki efek imunostimulator dengan menginduksi aktivitas proimflamasi dari sel T helper dan makrofag (Alkie et al, 2017). PLGA menginduksi proinflamasi dengan meningkatkan ekspresi IL-1 $\beta$ dan TNF- $\alpha$ pada sel T helper dan makrofag (Alkie et al, 2017). Selain itu, PLGA juga dapat meningkatkan ekspresi IFN tipe I seperti IFN- $\gamma$ dan IFN- $\beta$ yang nantinya akan meningkatkan aktivitas antiviral dari makrofag, limfosit $B$, dan sel $T$ sitotoksik (Alkie et al, 2017; Hølvold et al, 2013). Peningkatan aktivitas makrofag, limfosit B, dan sel T sitotoksik akan menjadi semakin aktif dalam mengeradikasi HIV-1 dalam tubuh (Hølvold et al, 2013).

\section{KESIMPULAN}

Penggunaan kitosan dan PLGA-PEG sebagai mekanisme konstruksi dari NARN-18 dapat meningkatkan drug loading dan drug release dari Analog $\mathrm{RN}-18$ yang diadministrasikan secara peroral untuk kenyamanan dalam penggunaan. Mekanisme kerja dari NARN-18 ini adalah dengan adminstrasi secara peroral NARN-18 akan melewati GI tract, NARN-18 yang terenkapsulasi dengan kitosan akan 
Potensi Nano Analog RN-18 (NARN-18) Berbasis Nanopartikel PLGA-CS-PEG dalam...

Gede Setula Narayana, I Kadek Wahyu Putra Dyatmika, Widia Danis Swari,

I Gede Putu Supadmanaba

melindungi NARN-18 sehingga mencapai

usus halus dan diabsorpsi kemudian berdifusi ke dalam sistem sirkulasi sistemik dan mencapai jaringan yang terdapat sel target. Setelah masuk ke dalam sel target, Analog RN-18 akan berikatan pada kompleks Vif-A3G dalam sel inang dan merangsang degradasi Vif sehingga enzim A3G dapat tetap ada di dalam sel dan melakukan fungsinya sebagai host restriction factor. Analisis manfaat dari molekul NARN-18 ini yaitu dapat menghambat pertumbuhan virus di dalam tubuh serta dapat berperan sebagai agen pencegahan infeksi HIV-1.

\section{SARAN}

Perlu dilakukan penelitian lebih lanjut secara in vivo untuk dapat mengetahui bagaimana farmakodinamik dan farmakokinetik dari $\mathrm{RN}-18$ dan molekul analognya serta pemilihan dosis yang tepat dan lamanya waktu terapi menggunakan modalitas ini.

Perlu dilakukan penyempurnaan mengenai efektivitas kombinasi dan metode konstruksi NARN-18, untuk dapat menghasilkan agen terapi dan pencegahan infeksi HIV yang memenuhi kriteria ideal dengan efek klinis yang lebih bermakna.

\section{DAFTAR PUSTAKA}

Adolph M, Webb J, dan Chelico L, 2013. Retroviral Restriction Factor
APOBEC3G Delays the Initiation of DNA Synthesis by HIV-1 Reverse Transcriptase. PLOS ONE. 8(5): e64196.

Aguilar Z, 2013. Targeted Drug Delivery. Nanomaterials for Medical Applications: 181-234.

Alkie TN, Taha-Abdelaziz K, Barjesteh N, Bavananthasivam J, Hodgins DC and Sharif S, 2017. Characterization of innate responses induced by PLGA encapsulated-and soluble TLR ligands in vitro and in vivo in chickens. PLoS One.12(1): e0169154.

Andrew A and Strebel K, 2014. HIV-1 Accessory Proteins: Vpu and Vif. Methods Mol Biol. 1087: 135-158.

Armitage $\mathrm{AE}$, Deforche $\mathrm{K}$, Chang $\mathrm{CH}$, Wee $\mathrm{W}$, Kramer B, et al, 2012. APOBEC3GInduced Hypermutation of Human Immunodeficiency Virus Type-1 Is Typically a Discrete "All or Nothing" Phenomenon. PLoS Genetics. 8(3): e1002550.

Cadima-Couto I and Goncalves J, 2010. Towards Inhibition of Vif-APOBEC3G Interaction: Which Protein to Target?. Adv Virol. 2010: 1-10.

Chandra E, Mudhakir D, and Ws AH, 2014. Studi Biodistribusi Dan Farmakokinetik Nanokarier PLGAPoloxamer Bertanda Radioisotop 
Iodium-131 Pada Mencit. Research

and Development on

Nanotechnology in Indonesia.1(2): 39-47.

Chaurasiya KR, McCauley MJ, Wang W, Qualley DF, Wu T, et al 2013. Oligomerization Transforms Human APOBEC3G From an Efficient Enzyme to a Slowly Dissociating Nucleic Acid-Binding Protein. Nature Chemistry. 6(1): 28-33.

Cimarelli A and Darlix J, 2014. HIV-1 Reverse Transcription. Methods Mol Biol. 1087: 55-70.

Cihlar T, and Ray AS, 2010. Nucleoside and Nucleotide HIV Reverse Transcriptase Inhibitors: 25 Years After Zidovudine. Antiviral Res. 85(1): 39-58.

Collins D and Collins K, 2014. HIV-1 Accessory Proteins Adapt Cellular Adaptors to Facilitate Immune Evasion. PLoS Pathogens. 10(1): e1003851.

Das A, Harwig A and Berkhout B, 2011. The HIV-1 Tat Protein Has a Versatile Role in Activating Viral Transcription. Journal of Virology. 85(18): 9506-9516.

Fairley SJ, Singh SR, Yilma AN, Waffo $A B$, Subbarayan P, et al, 2013. Chlamydia Trachomatis Recombinant MOMP Encapsulated in PLGA Nanoparticles Triggers
Primarily $\mathrm{T}$ helper 1 Cellular and Antibody Immune Responses in Mice: a Desirable Candidate Nanovaccine. International Journal of Nanomedicine. 8: 2085-2099.

Desimmie BA, Delviks-Frankenberry KA, Burdick R, Qi D, Izumi T, et al, 2014. Multiple APOBEC3 Restriction Factors for HIV-1 and One Vif to Rule Them All. Journal of molecular biology. 426(6): 1220-1245.

Ebrahimian $M$, Hashemi $M$, Maleki $M$, Abnous K Hashemitabar G, 2016. Induction of a Balanced Th1/Th2 Immune Responses by Co-Delivery of PLGA/Ovalbumin Nanospheres and Cpg Odns/PEI-SWCNT Nanoparticles as TLR9 Agonist in BALB/C Mice. International journal of pharmaceutics. 515(1-2): 708720.

Engelman A, and Cherepanov P, 2012. The Structural Biology of HIV-1: Mechanistic and Therapeutic Insights. Nature Reviews Microbiology. 10(4): 279-290.

Hajimahdi Z and Zarghi A, 2016. Progress in HIV-1 Integrase Inhibitors: A Review of their Chemical Structure Diversity. Iran J Pharm Res. 15(4): 595-628.

Hamdy S, Haddadi A, Shayeganpour A, Samuel J and Lavasanifar A, 2011. 
Potensi Nano Analog RN-18 (NARN-18) Berbasis Nanopartikel PLGA-CS-PEG dalam...

Gede Setula Narayana, I Kadek Wahyu Putra Dyatmika, Widia Danis Swari,

I Gede Putu Supadmanaba

Activation of Antigen-Specific T Cell-

Responses by Mannan-Decorated

PLGA Nanoparticles. Pharm Res. 28(9): 2288-2301.

Hølvold L, Fredriksen B, Bøgwald J and Dalmo

$\mathrm{R}$, 2013. Transgene and Immune Gene Expression Following Intramuscular Injection of Atlantic Salmon (Salmo Salar L.) With DNAReleasing PLGA Nano-And Microparticles. Fish \& shellfish immunology. 35(3): 890-899.

Hu W and Hughes S, 2012. HIV-1 Reverse Transcription. Cold Spring Harb Perspect Med. 2(10): a006882.

Khan $\mathrm{N}$, Jameel J, Jameel $\mathrm{N}$ and Rheman $\mathrm{S}$, 2017. An overview: Biosynthesized Nanoparticles with their Potential Applications. Glob J Nano. 2(1): 5-8.

Kobayashi T, Koizumi Y, Takeuchi JS, Misawa

$\mathrm{N}$, Kimura Y, et al, 2014. Quantification of Deaminase Activity-Dependent and Independent Restriction of HIV-1 Replication Mediated by APOBEC3F and $A P O B E C 3 G$ through

Experimental-Mathematical Investigation. Journal of Virology. 88(10): 5881-5887.

Kumar A, Vimal A, Kumar A. 2016. Why Kitosan? From properties to Perspective of Mucosal Drug
Delivery. Int J Biol Macromol. 91:615-22.

Li J, Mao J, Tang J, Li G, Fang F, et al, 2017. Surface Spermidine Functionalized Pegylated Poly(Lactide-CoGlycolide) Nanoparticles for TumorTargeted Drug Delivery. RSC Advances. 7(37): 22954-22963.

Lucas S dan Nelson A, 2014. HIV and the Spectrum of Human Disease. The Journal of Pathology. 235(2): 229241.

Maartens G, Celum C, Lewin SR, 2014. HIV Infection: Epidemiology, Pathogenesis, Treatment, and Prevention. The Lancet. 384(9989): 258-271.

Madani $\mathrm{N}$ and Kabat D, 2000. Cellular and Viral Specificities of Human Immunodeficiency Virus Type 1 Vif Protein. Journal of virology. 74(13): 5982-5987.

Malatesta M, Grecchi S, Chiesa E, Cisterna B, Costanzo M, et al, 2015. Internalized Chitosan Nanoparticles Persist for Long Time in Cultured Cells. Eur J Histochem. 59(1): 17-21.

Nathans R, Cao H, Sharova N, Ali A, Sharkey $\mathrm{M}$, et al, 2008. Small-molecule Inhibition of HIV-1 Vif. Nature Biotechnology. 26(10): 1187-1192.

Neeta MM, Satija S, Pandey P, and Dahiya M, 2016. Relevance of Ionotropic 
Gelation Technique in the Development of Floating

Multiparticulate Drug Delivery Systems. Int J Adv Sci Research. 1(4):

54-59.

Okada A and Iwatani Y, 2016. APOBEC3GMediated G-To-A Hypermutation of the HIV-1 Genome: the Missing Link in Antiviral Molecular Mechanisms. Frontiers in microbiology. 7: 2027.

Parveen S and Sahoo S, 2011. Long Circulating Chitosan/PEG Blended PLGA Nanoparticle for Tumor Drug Delivery. European Journal of Pharmacology. 670(2-3): 372-383.

Rafiei P and Haddadi A, 2017. Docetaxelloaded PLGA and PLGA-PEG Nanoparticles for Intravenous Application: pharmacokinetics and biodistribution profile. Int $J$ of Nanomedicine. 12: 935-947.

Rawson J, Landman S, Reilly C and Mansky L, 2015. HIV-1 and HIV-2 Exhibit Similar Mutation Frequencies and Spectra in the Absence of G-to-A Hypermutation. Retrovirology. 12(1): 60

Sarti F, Perera G, Hintzen F, Kotti K, Karageorgiou V, et al, 2011. In Vivo Evidence of Oral Vaccination with PLGA Nanoparticles Containing the Immunostimulant Monophosphoryl
Lipid A. Biomaterials. 32(16): 40524057.

Seitz R, 2016. Human Immunodeficiency Virus (HIV). Transfusion Medicine and Hemotherapy. 43(3): 203-222.

Sharma A, Vora R, Modi M, Sharma A, and Marfatia Y, 2008. Adverse effects of Antiretroviral Treatment. Indian J Dermatol Venereol Leprol. 74(3): 234-237.

Sheehy AM, Gaddis NC, Choi JD, Malim MH, 2002. Isolation of a Human Gene that Inhibits HIV-1 Infection and is Suppressed by the Viral Vif Protein. Nature. 418(6898): 646-650.

Simon V, Bloch N and Landau N, 2015. Intrinsic Host Restrictions to HIV-1 and Mechanisms of Viral Escape. Nature Immunology. 16(6): 546-553.

Taamalli A, Contreras MDM, Abu-Reidah, IM, Trabelsi N, and Ben Youssef N, 2019. Quality of Phenolic Compounds: Occurrence, Health Benefits, and Applications in Food Industry. Journal of Food Quality. 2019.

The Joint United Nations Programme on HIV/AIDS (UNAIDS), 2019. Indonesia.

https://www.unaids.org/en/regions countries/countries/indonesia

Usach I, Melis V and Peris JE, 2013. Non-Nucleoside Reverse 
Potensi Nano Analog RN-18 (NARN-18) Berbasis Nanopartikel PLGA-CS-PEG dalam...

Gede Setula Narayana, I Kadek Wahyu Putra Dyatmika, Widia Danis Swari,

I Gede Putu Supadmanaba

Transcriptase Inhibitors: A Review on Pharmacokinetics,

Pharmacodynamics, Safety and

Tolerability. Journal of the International AIDS Society. 16(1): 18567.

Wang X, Ao Z, Chen L, Kobinger G, Peng J, et al, 2012. The Cellular Antiviral Protein APOBEC3G Interacts with HIV-1 Reverse Transcriptase and Inhibits its Function during Viral Replication. Journal of Virology. 86(7): 3777-3786.

Wang Z, Wakae K, Kitamura K, Aoyama S, Liu $\mathrm{G}$, et al, 2013. APOBEC3 Deaminases Induce Hypermutation in Human Papillomavirus 16 DNA upon Beta Interferon Stimulation. Journal of Virology. 88(2): 1308-1317.

Weil AF, Ghosh D, Zhou Y, Seiple L, McMahon MA et al, 2013. Uracil DNA Glycosylase Initiates Degradation Of HIV-1 Cdna Containing Misincorporated Dutp and Prevents Viral Integration. PNAS. 110(6): E448-E457.

Wensing $A$, van Maarseveen $\mathrm{N}$, and Nijhuis $M, 2010$. Fifteen Years of HIV Protease Inhibitors: Raising the
Barrier to Resistance. Antiviral Research. 85(1): 59-74.

Wilen C, Tilton J, and Doms R, 2012. HIV: Cell Binding and Entry. Cold Spring Harbor Perspectives in Medicine. 2(8): a006866-a006866.

Wu G, Zhou F, Ge L, Liu X and Kong F, 2012. Novel Mannan-PEG-PE Modified Bioadhesive PLGA Nanoparticles for Targeted Gene Delivery. Journal of Nanomaterials. 2012(11): 1-9.

Yeh T, Hsu L, Tseng M, Lee P, Sonjae K, Ho Y and Sung H, 2011. Mechanism and Consequence of Chitosan-mediated Reversible Epithelial Tight Junction Opening. Biomaterials. 32(26): 6164-6173.

Zhang J, Zhu $X$, Jin $Y$, Shan $W$ and Huang $Y$, 2014. Mechanism Study of Cellular Uptake and Tight Junction Opening Mediated by Goblet Cell-Specific Trimethyl Chitosan Nanoparticles. Molecular Pharmaceutics. 11(5): 1520-1532.

Zhao $R$ and Bukrinsky $M$, 2014. HIV-1 Accessory Proteins: VpR. Methods Mol Biol. 1087: 125-134. 
ISSN 1978-2071 (Print); ISSN 2580-5967 (Online) Jurnal IImiah Kedokteran Wijaya Kusuma 9(2) : 190-208, September 2020

Zhou M, 2017. Synthesis, Biological Evaluation and Molecular Docking

Study of N -(2-Methoxyphenyl)-6((4-Nitrophenyl)Sulfonyl) Benzamide
Derivatives as Potent HIV-1 Vif Antagonists. Eur J Med Chem. 129: 310-324. 